\title{
Türkiye'deki Enerji Sektörü Çalışanlarının Risk Odaklı İç Denetimle İlgili Görüşlerine İlişskin Bir Araştırma
}

\section{Research on the Opinion of Turkey's Energy Sector Employees Related to Risk-Based Internal Auditing}

\author{
Gökhan Ömer Karlıdağ $\breve{g}^{1}$ \\ 'DR., S.M.M.M., C.F.E., K.G.K. Bağımsız Denetçi, İç Denetim Yöneticisi, İstanbul, Türkiye \\ ORCID: G.Ö.K. 0000-0002-2354-5543
}

\section{ÖZ}

Günümüzde iç denetim, işletme içinde tesis edilen iç kontrol mekanizmalarının etkin ve verimli yürütülüp yürütülmediğini değerlendirmesinin yanı sıra işletme risklerini de tanımlayıp, izleyerek risk yönetim süreçlerini de desteklemeye çalışmaktadır. Bir diğer deyişle, iç denetçiler yürüttükleri denetim faaliyetlerinde işlem ve hata odaklı yaklaşımın yanı sıra süreçlerin etkin yönetilip yönetilmediğini tespit etme fonksiyonunu da üstlenmeye başlamıştır. İşletme faaliyetleri risklerle etkileşim halindedir. Alınan stratejik, finansal ve operasyonel kararlar işletme faaliyetlerinde belirsizlikler yaratabilir. Bu belirsizliklerin bazıları işletme faaliyetlerine şans eseri pozitif etkide bulunurken, bazı etkiler ise risk olarak nitelenerek işletme faaliyetlerinde olumsuz sonuçlar yaratır. Stratejik, finansal ve operasyonel kararların değerlendirilip işletmeye olan veya olacak olan etkilerinin değerlendirilmesi ancak risk odaklı iç denetim yaklaşımıyla sağlanabilmektedir.

Bu çalışmada, Türkiye'de enerji sektöründe işletmelerin yüz yüze kaldığı riskler, risk odaklı iç denetim uygulamalarıyla ilgili sektör çalışanlarının görüşlerine ilişkin bilgi sahibi olmak amacıyla Türkiye'de enerji sektöründe faaliyet gösteren işletme çalışanları ve bu çalışanların yöneticilerine anket yapılarak, çalışanların ankete verdikleri yanıtlar değerlendirilmiştir.

Anahtar kelimeler: Türkiye'de Enerji Sektörü, Risk Odaklı İç Denetim, Risk Yönetimi

\section{ABSTRACT}

Currently, internal audits support risk management processes by identifying and monitoring the business risks. They also examine whether the internal control mechanisms established within the enterprise are carried out effectively and efficiently. In other words, internal auditors' activities include a transaction and error-oriented approach, and they have begun to determine whether the processes are managed effectively. Business activities are always intertwined with risks. Almost all strategic, financial, and operational decisions may contain uncertainties. Some of these uncertainties positively affect business activities by chance, while some of these uncertainties are considered risks and have negative results. Evaluation of the strategic, financial, and operational decisions and their impacts on the company can only be achieved through a risk-based internal audit.

This study used a questionnaire to gather information about the risks faced by publicly traded and non-publicly traded enterprises operated in Turkey's energy sector. The questionnaire also explored energy sector employees' opinions of risk-based internal audit practices. The responses to the questionnaire were then evaluated and analyzed.

Keywords: Energy Sector in Turkey, Risk-Based Internal Audit, Risk Management

Başvuru/Submitted: 16.11.2020 Revizyon Talebi/Revision Requested: 03.12.2020 Son Revizyon/Last Revision Received: 15.12.2020 Kabul/Accepted: 18.01.2020 Sorumlu yazar/Corresponding author: Gökhan Ömer Karlıdağ / gokhan.karlidag@gmail.com 


\section{Extended Abstract}

Through growth of the enterprise scale, businesses and operations have become more complex. The peculiarities of the sector and limited operating resources have made risk-based planning and implementation of internal audit processes and activities necessary. Therefore, large-scale enterprises have needed to use a risk-based internal audit approach for the sustainability of the corporate growth, saving of operational costs and time. Risk-based internal audit approach also contributes to the effectiveness of internal audit in audit activities. It is generally accepted that the risk assessment process is important for internal audit departments to carry out risk-based internal audit activities. The process is also needed to establish an internal control system in institutions. The purpose of this study is to examine the role of the risk-based internal audit practice, which is the most important tool in ensuring corporate risk management in business activities.

The energy sector has strategic importance for the Turkish economy. For the Turkey energy sector, it is essential consistently plan profitability and growth strategies by establishing appropriate risk management policies. It is critically important to establish the risk control mechanisms, analysis, and determination of the appropriate risk limits by considering the probability of the risks. In that process, businesses need advice about risk management. Evaluation of the strategic, financial, and operational decisions and the ways their risks impact the company can only be achieved through a risk-based internal audit approach.

In implementing the risk-based internal audit, the questionnaire explored the evaluations and thoughts of Turkish energy sector employees about the importance of the studies related to the management of financial and operational risk factors. The survey consists of ranking questions and the 5-point Likert scale. This study is the first survey on risk-based internal audits in Turkey's energy sector.

The ability of businesses to continue healthy activities depends on rational determination of their future investment and financing plans. In that process, it is also crucial to try to keep financial structures strong in a controlled manner. It is well known that Turkey's energy sector has billions of dollars in debt, and their debt ratio has increased in recent years. Participants also view macroeconomic and financing risks as significant and think that internal auditors should guide business management to control and evaluate a firm's macroeconomic and financing risks by conducting a risk-based internal audit.

When participants evaluate their firms' existing risks in according to their importance, macroeconomic, financing, and operational risks were considered as important in the inherent risk group. In addition, internal control risks, information technology risks, and financial risks were regarded as important.

The research findings support the conclusion that risk-based internal audits in Turkish energy sector businesses significantly depend on the presence of a risk management department in the organizational structure. In other words, the level of implementation of risk-based internal audits in Turkey's energy sector businesses vary according to the presence of a risk management department. This study also concludes that the application level of risk-based internal audit on businesses is affected by the businesses' foreign partnership and status as a publicly-traded company.

The risk-based internal audit approach plays an important role in identifying the issues that are open to abuse in the processes and in preventing losses that may be incurred due to fraudulent transactions and misconduct in the operational processes. The risk-based internal audit is also regarded as significant for evaluating and providing information to senior management about the effects of changes in price levels, foreign exchange, and interest rate changes arising from adverse situations in the financial markets. Participants think that the application of risk-based internal audit studies will provide operational efficiency and control of businesses' risks. 


\section{Giriş}

Değişim halinde olan dış çevre koşulları karşısında işletmelerin rekabet avantajlarında sürekliliğinin sağlanabilmesi, ekonomik faaliyet ortamındaki değişikliklere karşı etkili strateji ve proaktif aksiyonların geliştirilmesiyle mümkün olabilir. İşletmelerin etkin yönetimi, gerekli planlamaların önceden yapılabilmesi, risk yönetimi ve risk odaklı iç denetim faaliyet sonuçlarının karar alma süreçlerinde dikkate alınmasıyla elde edilebilir.

Belirlenen risk yönetim politikaları ve sistemlerinin faaliyet ve piyasa şartlarında yaşanan sürekli değişimleri yansıtacak şekilde düzenli olarak gözden geçirilmesi gerekmektedir. Enerji sektöründeki işletmeler faaliyetleri süresince operasyonel, finansal, stratejik, itibari, yasal ve dış çevre faktörlerinin doğuracağı risklerle karşı karşıya kalacaktır. Örneğin kur ve faiz oranlarındaki ani değişimlere karşı gereken önlemlerin alınması, üretimde verimliliğin sağlanması, yatırım akışının zamanında sağlanabilmesi, işletmenin değişen ar-ge ve teknolojik ilerlemeye ayak uydurabilmesi, yatırım planlarında gerekli fizibilitelerin yapılması enerji sektöründe faaliyet gösteren işletmelerin istikrarlı karlılık ve büyüme stratejilerinin belirlenmesinde anahtar rol oynayabilir. Çalışmada, risk odaklı iç denetim yöntem, araç ve teknikleri kullanılarak, enerji sektöründeki çalışanların işletmelerde faaliyetlerinin denetlenmesi, risklerin yönetilmesi ve risk odaklı iç denetimle ilgili görüşleriyle ilgili Türkiye' de enerji sektöründe faaliyet gösteren halka açık işletmelerin çalışanlarına bir anket çalışması yapılarak elde edilen sonuçlar değerlendirilmiştir.

\section{Riskin Tanımı ve Çeşitleri}

Risk, işletme faaliyetleri dikkate alındığında işletme operasyonları sırasında işletmenin maruz kalacağı muhtemel gelecekte meydana gelebilecek olay ve durumlar olarak tanımlanabilmektedir. Bir başka tanıma göre risk; hedefe ulaşmak için belirlenmiş sonuçlardan olası negatif sapmalar olarak açıklanabilir. (Göğüşs, 2012, s. 17)

İşletme faaliyetlerinde alınan stratejik, finansal ve operasyonel kararlar bazı belirsizlikleri içerebilir. Bu belirsizliklerin bazılarının işletme faaliyetlerine pozitif etkide bulunması, şans olarak adlandırılmaktayken söz konusu bazı etkilerin işletme faaliyetlerinde olumsuz sonuçlar yaratması ise risk olarak ifade edilir. (Gassmann \& Kobe, 2006, s.45) İşletmeler öncelikle planlanan hedeflerle işletmenin sahip olduğu veya olacağını düşündüğü riskler arasında denge kurup belirledikleri risk iştahları çerçevesinde ulaşacakları hedeflerini belirlerler. Risk $\dot{I}_{\boldsymbol{s}} \boldsymbol{t a h l}$; işletmenin stratejik hedeflerini gerçekleştirirken dikkate aldığı risk düzeyini ifade etmektedir. Yönetim öncelikle yüksek veya sınırlı riskli bir politika belirleyeceğine karar vermelidir. (Türedi ve ark., 2015, s.9)

İşletmelerin karşı karşıya oldukları ve yönetmeleri gereken riskler; doğal ve kalıntı riskler olmak üzere iki ana risk grubunda incelenir. Doğal risk işletmenin hiçbir önlem almadığı takdirde ortaya çıkan, iş yapısı ve işletme faaliyetlerinden kaynaklanan risk olarak ifade edilir. Kontrol riski; işletmenin oluşturacağı beşerî ve sistemsel kontrolleri, iç kontrol sistemleriyle yönetebileceği riskleri kapsar. Kalıntı (kalan) risk ise doğal riske karşı işletmenin gereken önlemleri almasına rağmen karşı karşıya kaldığı (artan) riskleri ifade etmektedir. (Beasley, 2014, s.14-38)

\section{3. İç Denetimde Risk Odaklı İç Denetim Yaklaşımı}

İç denetimden beklenen işletme amaçlarına ulaşmadaki riskin azaltılması veya mümkünse tamamen yok edilmesidir. İç denetim söz konusu riskleri azaltabildiği veya ortadan kaldırabildiği ölçüde başarılıdır. Ancak, iç denetimde fayda maliyetinin sistemin oluşturulma maliyetinden yüksek olması göz önünde bulundurulur. (Göğüş, 2012, s.49)

Modern anlayıştaki risk odaklı iç denetim, faaliyet denetimi, yönetsel denetimler ve finansal denetim olmak üzere üç ayrı bileşenden oluşan bir fonksiyondur. (PwC, 2006). Risk değerlendirmesi için öncelikle işletmenin bir katma değer elde etmek için göze aldığı risk miktarını ifade eden risk iştahının ve risk toleransının belirlenmesi gerekir. Yüksek risk iştahına sahip bir işletme sermayesinin büyük bir kısmını gelişmekte olan piyasalara ayırırken, düşük risk iştahına sahip bir işletme, sadece istikrarlı piyasalara yatırım yapmayı tercih edebilir. Risk toleransı, belli bir hedefin gerçekleştirilmesine ilişkin kabul edilebilir bir sapma derecesidir ve işletmenin hedefleriyle ilişkilidir. İyi geliştirilmiş, çalışanlar tarafından anlaşllıp benimsenmiş bir risk yönetimi felsefesine sahip olan işletme, riski etkili bir biçimde tanıma ve yönetme yetisine sahiptir. (Göğüş, 2012, s.50) 


\section{Literatür İncelemesi}

İşletmelerde risk odaklı iç denetimin uygulanması durumuyla işletmelerin sahip oldukları riskler arasındaki ilişkiyi inceleyen çalışma sayısı sınırlıdır. Gerçekleştirilen literatür araştırmalarında çoğunlukla işletmenin sahip olduğu finansal risk düzeyi ile risk odaklı iç denetimin uygulanma düzeyi arasındaki ilişki incelenmiştir.

Kara ve Yereli (2012), Türkiye'de Borsa İstanbul İmalat Sanayi Endeksine kayıtlı işletmelerde risk odaklı iç denetim ile finansal risk düzeyi arasındaki ilişkiye yönelik yaptığı araştırmada 47 işletmeyi değerlendirmeye almış, işletmelerin risk odaklı iç denetime verdiği önem arttıkça işletmenin finansal risk düzeyinin düştüğünü tespit etmiştir. Araştırmada risk yönetim uygulamasının nedenini finansal risklerden korunma ve daha etkin bir iç denetim ihtiyacının mevcudiyeti olarak tespit etmiştir. Ankete katılan işletmelerin $\% 55^{\prime}$ lik bölümü risk yönetim faaliyetlerini iç denetim biriminin yürüttüğünü ya da iç denetim departmanı ve risk yönetim birimi birlikte çalışarak yürüttüklerini belirtmiştir. Ankete katılan işletmelerin \%38'lik kısmı finansal risklere önem verdiklerini, diğer işletme risklerini geri plana attıklarını ifade etmiştir. Kara ve Yereli (2013), iç denetim faaliyetinde risk odaklı iç denetimin uygulanması durumu ile yabancı ortaklığın bulunması durumunu konu alan araştırmalarında yine 47 işletmeyi değerlendirmeye almış risk odaklı iç denetim uygulama düzeyi ile yabancı ortaklık oranı arasında önemli düzeyde pozitif ilişki tespit etmiştir.

\section{Araştırma Modeli, Veri Seti ve Metodoloji}

Araştırma modeli literatürde yer alan önceki çalışmalar, enerji sektörü çalışanlarından alınan bilgiler doğrultusunda geliştirilmiştir. İlk olarak risk odaklı iç denetimin uygulanma durumu ile işletmede risk yönetim birimi mevcudiyeti, işletmenin yabancı ortaklı olması, halka açı olması durumu arasında bağ olup olmadığı incelenmiştir. Sonrasında enerji sektörü çalışanlarının öne çıkan riskler olarak gördüğü işletmelerin makro ekonomi ve finansman risk düzeyi, operasyonel risk düzeyi ile iç denetçilerin söz konusu risklere yönelerek bu risklere ilişkin iç denetim çalışmaları gerçekleştirmeleri arasında ilişki olup olmadığı araştırılmıştır. Araştırma modeli tablo 1’ de yer almaktadır.

Tablo 1: Araştırma Modeli

\begin{tabular}{|c|c|c|}
\hline $\begin{array}{l}\text { Makro ekonomi ve finansman risk } \\
\text { düzeyi }\end{array}$ & $\rightarrow$ & $\begin{array}{l}\text { İç denetimin risk odaklı yaklaşımla kredili satış süreçlerine ilişkin satış } \\
\text { prosedürlerini belirleyerek yürütlecek süreçlere ilişkin tavsiyelerde } \\
\text { bulunması durumu } \\
\text { İç denetim departmanının, ülkede yaşanabilecek döviz kurlarındaki } \\
\text { dalgalanma durumuna karşı alınması gerektiğini düşündüğü önlemler } \\
\text { hakkında tavsiyelerde bulunması } \\
\text { İç denetim departmanının, finansal piyasalarda yaşanacak olumsuz } \\
\text { durumlardan kaynaklanan fiyat düzeyleri ve faiz oranlarında yaşanacak } \\
\text { değişimlerin etkilerini değerleyerek üst yönetime bilgi sunması }\end{array}$ \\
\hline $\begin{array}{l}\text { Risk odaklı iç denetim uygulanma } \\
\text { düzeyi }\end{array}$ & & $\begin{array}{l}\text { İşletmede risk yönetim birimi mevcudiyeti } \\
\text { İşletmenin yabancı ortaklı olması } \\
\text { İşletmenin halka açıklık durumu }\end{array}$ \\
\hline Operasyonel risk düzeyi & & $\begin{array}{l}\text { İç denetimin risk odaklı yaklaşımla operasyonlardaki verimsizlik sonucu } \\
\text { ortaya çıkabilecek sorun veya kesintilerin hizmet kalitesini, maliyetler } \\
\text { üzerindeki etkisini değerlendirmesi ve üst yönetime raporlaması durumu } \\
\text { İç denetimin risk odaklı yaklaşımla operasyonel süreçlerde hileli } \\
\text { işlemler/suiistimaller nedeniyle yaşayabileceği kayıları tespit etmesi } \\
\text { veya süreçlerdeki suiistimale açık hususları üst yönetime raporlaması }\end{array}$ \\
\hline
\end{tabular}


Araştırmada, çalışanların işletmelerde risklerin yönetilmesi, enerji sektöründe işletmelerin yüz yüze kaldığ1 riskler, risk odaklı iç denetim uygulamalarıyla ilgili görüşlerine ilişkin bilgi sahibi olmak amaçlanmıştır. Araştırma ana kütlesi Türkiye'de enerji sektöründe elektrik üretim, perakende, toptan satış, doğalgaz dağıtım iş kollarında faaliyet gösteren 186 işletmede çalışan personeldir. Araştırmada işletme seçimi, Türkiye'de enerji sektörünün enerji üretim, elektrik dağıtım ve doğalgaz dağıtım iş kollarında faaliyet gösteren işletmelerin satış hacim büyüklükleri dikkate alınarak örneklem yoluyla gerçekleştirilmiştir. Araştırma için Türkiye'de enerji sektöründe faaliyet gösteren işletmelerin çeşitli departmanlarında çalışan personel ve personelin yöneticilerine e-posta yoluyla anket gönderilmiştir. Araştırma kapsamında olan bütün firmalara ulaşılmak istenmiş olmasına karşın 72 işletmede çalışan katılımcı, yani araştırma kapsamındaki firmaların yaklaşık yüzde 39' u ankete cevap vermiştir. Bu oran analizlerimizin doğru olarak yapılabilmesi için uygundur. Çalışanların işletmelerde risklerin yönetilmesi, enerji sektöründe işletmelerin yüz yüze kaldığı riskler ve risk odaklı iç denetim uygulamalarıyla ilgili görüşlerine ilişkin bilgi sahibi olmak amacıyla anket hazırlanmıştır. İşletmelerden gelen cevaplar Microsoft Excel Programı’na aktarılarak değerlendirilmiş ve veriler SPSS programında analiz edilmiştir.

Enerji sektöründe risk odaklı iç denetim uygulanma düzeyi ile işletmede risk yönetim birimi mevcudiyeti, yabancı ortaklı olması, halka açıklık durumu arası ilişkinin incelenmesi, işletmenin makro ekonomi ve finansman risk düzeyi ile iç denetimin döviz kurlarındaki, faiz oranlarındaki, fiyatlardaki değişimlerle ilgili risk analizleri yapması arası ilişki durumunun incelenmesi, ayrıca yine makro ekonomi ve finansman risk düzeyi ile iç denetimin risk odaklı yaklaşımla kredili satış faaliyetlerinin yürütülmesine ilişkin satış politikaları belirlemesi ve bu konuda tavsiyelerde bulunması durumu, operasyonel süreçlerde hileli işlemler/suiistimaller, operasyonlardaki verimsizlik nedeni ile yaşanabilecek kayıplar, maliyet artışlarının tespit edilmesi ve üst yönetime raporlanması durumu arasında anlamlı bir bağ olup olmadığını ölçmek amacıyla yapılan anket çalışması ile elde edilen verilerin analizinde yüzde, frekans, ortalama gibi tanımlayıcı istatistik yöntemleri kullanılmıştır. Yapılan istatistiksel analizlerde parametrik olmayan, Ki Kare Bağımsızlık, Pearson ve Spearman testleri kullanılmıştır.

Risk odaklı iç denetim, işletme riskleri, işletme ortaklık yapısı, halka açıklık durumu ve işletmenin yabancı ortaklı olmasına yönelik hazırlanan sorular arasında bir korelasyon olup olmadığının belirlenmesi için yapılan güvenirlik seviyesini ölçen KMO - Bartlett testi sonucuna göre alfa (Cronbach’s Alpha) katsayısının 0,663 değerinde olduğu tespit edilmiştir. Cronbach alfa katsayısı ile yapılan güvenirlik testinde ölçeğin KMO örnekleme yeterliliğinin kabul edilebilir en alt sınır olan \%50 üzerinde bir değerde olması sebebiyle kabul edilebilir $(\% 66,3)$ güvenirliğe sahip olduğu söylenebilir.

Çalışmada aşağıda yer alan sekiz araştırma hipotezine yanıt aranmıştır:

$\mathrm{H}_{1}$ : Enerji sektöründe risk odaklı iç denetim uygulanma düzeyi şirkette risk yönetim birimi mevcudiyetine göre farklılık gösterir.

$\mathrm{H}_{2}$ : Enerji sektöründe risk odaklı iç denetim uygulanma düzeyi işletmenin yabancı ortaklı olmasına göre farklılık gösterir.

$\mathrm{H}_{3}$ : Enerji sektöründe risk odaklı iç denetim uygulanma düzeyi işletmenin halka açıklık durumuna göre farklılık gösterir.

$\mathrm{H}_{4}$ : Makro ekonomi ve finansman risk düzeyi ile iç denetim departmanının, ülkede yaşanabilecek döviz kurlarındaki dalgalanma durumuna karşı alınması gerektiği düşündüğü önlemler hakkında tavsiyelerde bulunması durumu arasında istatistiki olarak anlamlı bir ilişki vardır.

$\mathrm{H}_{5}$ : Makro ekonomi ve finansman risk düzeyi ile iç denetim departmanının, finansal piyasalarda oluşacak olumsuz durumlardan kaynaklanan fiyat düzeyleri ve faiz oranlarında meydana gelen değişimlerin etkilerini değerleyerek üst yönetime bilgi sunması durumu arasında istatistiki olarak anlamlı bir ilişki vardır.

$\mathrm{H}_{6}$ : Makro ekonomi ve finansman risk düzeyi ile iç denetimin risk odaklı yaklaşımla kredili satış süreçlerine ilişkin satış prosedürlerini belirleyerek yürütülecek süreçlere ilişkin tavsiyelerde bulunması durumu arasında istatistiki olarak anlamlı bir ilişki vardır. 
$\mathrm{H}_{7}$ : Türkiye'de enerji sektöründe faaliyet gösteren işletmelerin operasyonel risk düzeyleri ile iç denetimin risk odaklı yaklaşımla operasyonlardaki verimsizlik sonucu ortaya çıkabilecek sorun veya kesintilerin hizmet kalitesini, maliyetler üzerindeki etkisini değerlendirmesi ve üst yönetime raporlaması durumu arasında istatistiki olarak anlamlı bir ilişki vardır.

$\mathrm{H}_{8}$ : Türkiye'de enerji sektöründe faaliyet gösteren işletmelerin operasyonel risk düzeyleri ile iç denetimin risk odaklı yaklaşımla operasyonel süreçlerde hileli işlemler/suiistimaller nedeniyle yaşayabileceği kayıpları tespit etmesi veya süreçlerdeki suiistimale açık hususları üst yönetime raporlaması durumu arasında istatistiki olarak anlamlı bir ilişki vardir.

\section{Bulgular}

Risk odaklı iç denetimin uygulanmasında finansal ve operasyonel risk faktörlerinin yönetimi ile ilgili işletmelerince gerçekleştirilen veya gerçekleştirilmesi planlanan çalışmaların önem derecesi ile ilgili görüşlere ilişkin değerlendirmeler 5'li likert ölçeğinde hazırlanan “(1) Kesinlikle Katılmıyorum - (5) Kesinlikle Katılıyorum” ve önem derecesine göre 5'den 1'e sıralama yöntemi ile derecelendirilen anket ile analiz edilerek, katılımcıların düşüncelerinin ne olduğu hakkında fikir sahibi olmaya çalışılmıştır. Katılımcılar öncelikli olarak iç denetimin risk odaklı yaklaşımla operasyonel süreçlerde hileli işlemler, suiistimaller nedeni ile yaşayabileceği kayıpları tespit etmesi veya süreçlerdeki suiistimale açık hususları üst yönetime raporlanmasının ve finansal piyasalarda yaşanacak olumsuz durumlardan kaynaklanan fiyat düzeyleri ve faiz oranlarında yaşanacak değişimlerin etkilerini değerleyerek üst yönetime bilgi sunulmasının işletmeleri için önemli olduğunu düşünmektedir.

\subsection{Enerji Sektöründe Risk Odaklı İç Denetim Uygulanma Düzeyi İle İşletmede Risk Yönetim Birimi Mevcudiyeti, İşletmenin Halka Açıklık Durumu, Yabancı Ortaklık Durumu Arasındaki İlişki}

Değişkenler arası korelasyon durumunun tespiti için Pearson ve Spearman Korelasyon Testinden yararlanılmıştır. Korelasyon tabloları incelendiğinde risk odaklı iç denetimin uygulanma durumu ile risk yönetim bölümü mevcudiyet durumu arasında Pearson ve Spearman Korelasyon Testinde 0,87 kuvvetinde önemli düzeyde kuvvetli ve pozitif bir ilişki olduğu, işletmelerin yabancı ortaklık durumu ile arasında 0,593 kuvvetinde, halka açıklık durumu ile arasında ise 0,518 kuvvetinde pozitif ilişki olduğu tespit edilmiştir. (Bkz. Tablo 2)

Coefficients $^{\text {a }}$

\begin{tabular}{|c|c|c|c|c|c|c|c|}
\hline \multirow{2}{*}{ Model } & \multirow{2}{*}{\multicolumn{2}{|c|}{$\begin{array}{l}\text { Unstandardized } \\
\text { Coefficients }\end{array}$}} & \multirow{3}{*}{$\begin{array}{c}\text { Standardized } \\
\text { Coefficients }\end{array}$} & \multirow{3}{*}{$\mathrm{t}$} & \multirow{3}{*}{ Sig. } & \multicolumn{2}{|c|}{ Collinearity Statistics } \\
\hline & & & & & & \multirow{2}{*}{ Tolerance } & \multirow{2}{*}{ VIF } \\
\hline 1 (Constant) & B & Std. Error & & & & & \\
\hline $\begin{array}{l}\text { Riskyönmevcudiyeti } \\
2\end{array}$ & $\begin{array}{l}148 \\
, 926\end{array}$ & $\begin{array}{l}, 083 \\
, 063\end{array}$ & 870 & $\begin{array}{l}1,789 \\
14,79\end{array}$ & $\begin{array}{l}078 \\
, 000\end{array}$ & 1,000 & 1,000 \\
\hline
\end{tabular}

a. Risk odaklı iç denetim uygulanma durumu

Regresyon Modeli: Risk odaklı iç denetim uygulanma durumu = 0,148+0,926 (Risk yönetim bölümü mevcudiyeti) $+\varepsilon$

Coefficients $^{\text {a }}$

\begin{tabular}{|c|c|c|c|c|c|c|c|}
\hline \multirow{2}{*}{ Model } & \multirow{2}{*}{\multicolumn{2}{|c|}{$\begin{array}{c}\text { Unstandardized } \\
\text { Coefficients }\end{array}$}} & \multirow{3}{*}{$\begin{array}{c}\text { Standardized } \\
\text { Coefficients }\end{array}$} & \multirow[b]{3}{*}{$\mathrm{t}$} & \multirow[b]{3}{*}{ Sig. } & \multicolumn{2}{|c|}{ Collinearity Statistics } \\
\hline & & & & & & & \\
\hline 1 (Constant) & $\mathrm{B}$ & Std. Error & & & & Toterante & VIT \\
\hline $\begin{array}{l}\text { Yortak } \\
2\end{array}$ & $\begin{array}{l}, 450 \\
, 550\end{array}$ & $\begin{array}{l}, 146 \\
, 089\end{array}$ & ,593 & $\begin{array}{l}3,090 \\
6,166\end{array}$ & $\begin{array}{l}, 003 \\
, 000\end{array}$ & 1,000 & 1,000 \\
\hline
\end{tabular}

a. Bağımlı Değişken: Risk odaklı iç denetim uygulanma durumu

Regresyon Modeli: Risk odakı iç denetim uygulanma durumu $=0,45+0,55$ (İşletmenin yabancı ortaklık durumu) $+\varepsilon$ 
Coefficients $^{\text {a }}$

\begin{tabular}{|c|c|c|c|c|c|c|c|}
\hline \multirow{3}{*}{$\frac{\text { Model }}{1 \text { (Constant) }}$} & \multirow{2}{*}{\multicolumn{2}{|c|}{$\begin{array}{c}\text { Unstandardized } \\
\text { Coefficients }\end{array}$}} & \multirow{3}{*}{$\begin{array}{c}\text { Standardized } \\
\text { Coefficients }\end{array}$} & \multirow{3}{*}{$\mathrm{t}$} & \multirow{3}{*}{ Sig. } & \multicolumn{2}{|c|}{ Collinearity Statistics } \\
\hline & & & & & & \multirow{2}{*}{ Tolerance } & \multirow{2}{*}{ VIF } \\
\hline & $\mathrm{B}$ & Std. Error & & & & & \\
\hline $\begin{array}{l}\text { Halkaacik } \\
2\end{array}$ & $\begin{array}{l}, 519 \\
, 690\end{array}$ & $\begin{array}{l}, 162 \\
, 136\end{array}$ & ,518 & $\begin{array}{l}3,205 \\
5,070\end{array}$ & $\begin{array}{l}, 002 \\
, 000\end{array}$ & 1,000 & 1,000 \\
\hline
\end{tabular}

a. Bağımlı Değişken: Risk odaklı iç denetim uygulanma durumu

Regresyon Modeli: Risk odaklı iç denetim uygulanma durumu $=\mathbf{0 , 5 1 9 + 0 , 6 9}($ İşletmenin halka açıklık durumu) $+\varepsilon$

Risk odaklı iç denetim uygulanma durumu ile işletmede risk yönetim bölümü mevcudiyeti, halka açıklık durumu ve yabancı ortaklı olma durumu değişkenleri arasındaki ilişkiyi ölçen Ki Kare Testi sonuçları değerlendirildiğinde, Pearson Ki-Kare ve Spearman rho anlamlılık değerinin 0,00 olduğu tespit edilmiştir. Bu değer 0,05 değerinden küçük olması sebebiyle Ho hipotezi reddedilir. Yani, enerji sektöründe risk odaklı iç denetim uygulanma düzeyi işletmede risk yönetim birimi mevcudiyeti, işletmenin yabancı ortaklık ve halka açıklık durumuna göre farklılık göstermektedir.

\begin{tabular}{|c|c|c|c|}
\hline & $\begin{array}{c}\text { Risk yönetim bölümü } \\
\text { mevcudiyeti }\end{array}$ & Halka Açıklık Durumu & $\begin{array}{c}\text { Yabancı Ortaklı Olma } \\
\text { Durumu }\end{array}$ \\
\hline $\begin{array}{l}\text { Risk odaklı iç denetim uygulanma durumu } \\
\text { Pearson Correlation } \\
\text { Chi-Square Tests Sig. (2-tailed) } \\
\text { Spearman's rho Sig. (2-tailed) } \\
\text { Correlation Coefficient }\end{array}$ & $\begin{array}{c}, 870(*) \\
, 000 \\
, 870(*) \\
, 000\end{array}$ & $\begin{array}{c}, 518(*) \\
, 000 \\
, 518(*) \\
, 000\end{array}$ & $\begin{array}{c}, 593(*) \\
, 000 \\
, 593(*) \\
, 000\end{array}$ \\
\hline
\end{tabular}

* Korelasyon 0,01 seviyesinde (2- yönlü) belirgindir.

6.2. Enerji Sektöründe İşletmelerin Makro Ekonomi ve Finansman Risk Düzeyi ile İç Denetim Departmanının, Ülkede Yaşanabilecek Döviz Kurlarındaki Dalgalanma Durumuna Karşı Alınması Gerektiği Düşündüğü Önlemler Hakkında Tavsiyelerde Bulunması Durumu Arasındaki İlişkinin İncelenmesi

Korelasyon tabloları incelendiğinde iç denetim departmanının, ülkede yaşanabilecek döviz kurlarındaki dalgalanma durumuna karşı alınması gerektiğini düşündüğü önlemler hakkında tavsiyelerde bulunması durumu ile işletmenin makro ekonomi ve finansman riskleri arasında Pearson Korelasyon Testinde 0,699 kuvvetinde önemli düzeyde pozitif bir ilişki olduğu, yine Spearman Korelasyon Testinde aynı düzeyde pozitif bir ilişki bulunduğu tespit edilmiştir. (Bkz. Tablo 3)

Coefficients $^{\text {a }}$

\begin{tabular}{|c|c|c|c|c|c|c|c|}
\hline \multirow{2}{*}{ Model } & \multirow{2}{*}{\multicolumn{2}{|c|}{$\begin{array}{c}\text { Unstandardized } \\
\text { Coefficients }\end{array}$}} & \multirow{2}{*}{$\begin{array}{c}\text { Standardized } \\
\text { Coefficients }\end{array}$} & \multirow[b]{2}{*}{$\mathrm{t}$} & \multirow{2}{*}{ Sig. } & \multicolumn{2}{|c|}{ Collinearity Statistics } \\
\hline & & & & & & Tolerance & VIF \\
\hline (Colis) & $\mathrm{D}$ & & & & & & \\
\hline $\begin{array}{l}\text { Makro Ekonomi ve } \\
\text { Finansman Riskleri } \\
2\end{array}$ & $\begin{array}{l}1,214 \\
, 705\end{array}$ & $\begin{array}{l}, 397 \\
, 086\end{array}$ & ,699 & $\begin{array}{l}3,059 \\
8,183\end{array}$ & $\begin{array}{l}, 003 \\
, 000\end{array}$ & 1,000 & 1,000 \\
\hline
\end{tabular}

a. Bağımlı değişken: İç denetim departmanının, ülkede yaşanabilecek döviz kurlarındaki dalgalanma durumuna karşı alınması gerektiği düşündüğü önlemler hakkında tavsiyelerde bulunması durumu

Regresyon Modeli: İç Denetim Departmanının, Ülkede Yaşanabilecek Döviz Kurlarındaki Dalgalanma Durumuna Karşı Alınması Gerektiği Düşündüğü Önlemler Hakkında Tavsiyelerde Bulunması Durumu = 1,214+0,705 (Makro ekonomi ve finansman riskleri) $+\varepsilon$ 
6.3. Enerji Sektöründe İşletmelerin Makro Ekonomi ve Finansman Risk Düzeyi ile İç Denetim Departmanının, Finansal Piyasalarda Oluşacak Olumsuz Durumlardan Kaynaklanan Fiyat Düzeyleri ve Faiz Oranlarında Meydana Gelen Değişimlerin Etkilerini Değerleyerek Üst Yönetime Bilgi Sunması Durumu Arasındaki İlişkinin İncelenmesi

Korelasyon tabloları incelendiğinde Türkiye'de enerji sektöründe faaliyet gösteren işletmelerin makro ekonomi ve finansman risk düzeyleri ile iç denetim departmanının, finansal piyasalarda oluşacak olumsuz durumlardan kaynaklanan fiyat düzeyleri ve faiz oranlarında meydana gelen değişimlerin etkilerini değerleyerek üst yönetime bilgi sunması durumu arasında Pearson Korelasyon Testinde 0,717 kuvvetinde önemli düzeyde pozitif bir ilişki olduğu, yine Spearman Korelasyon Testinde 0,723 kuvvetinde pozitif bir ilişki bulunduğu tespit edilmiştir.(Bkz. Tablo 3)

Coefficients $^{\text {a }}$

\begin{tabular}{|c|c|c|c|c|c|c|c|}
\hline \multirow{2}{*}{ Model } & \multirow{2}{*}{\multicolumn{2}{|c|}{$\begin{array}{c}\text { Unstandardized } \\
\text { Coefficients }\end{array}$}} & \multirow{3}{*}{$\begin{array}{c}\text { Standardized } \\
\text { Coefficients } \\
\text { Beta } \\
\end{array}$} & \multirow{3}{*}{$\mathrm{t}$} & \multirow{3}{*}{ Sig. } & \multicolumn{2}{|c|}{ Collinearity Statistics } \\
\hline & & & & & & \multirow{2}{*}{ Tolerance } & \multirow{2}{*}{ VIF } \\
\hline 1 (Constant) & $\mathrm{B}$ & Std. Error & & & & & \\
\hline $\begin{array}{l}\text { Makro Ekonomi ve } \\
\text { Finansman Riskleri } \\
2\end{array}$ & $\begin{array}{l}, 952 \\
, 762\end{array}$ & $\begin{array}{l}, 408 \\
, 089\end{array}$ &, 717 & $\begin{array}{l}2,331 \\
8,598\end{array}$ & $\begin{array}{l}, 023 \\
, 000\end{array}$ & 1,000 & 1,000 \\
\hline
\end{tabular}

a. Bağımlı değişken: İç denetim departmanının, finansal piyasalarda oluşacak olumsuz durumlardan kaynaklanan fiyat düzeyleri ve faiz oranlarında meydana gelen değişimlerin etkilerini değerleyerek üst yönetime bilgi sunması durumu

Regresyon Modeli: İç denetim departmanının, finansal piyasalarda oluşacak olumsuz durumlardan kaynaklanan fiyat düzeyleri ve faiz oranlarında meydana gelen değişimlerin etkilerini değerleyerek üst yönetime bilgi sunması durumu $=0,952+0,762($ Makro ekonomi ve finansman riskleri) $+\varepsilon$

6.4. Enerji Sektöründe İşletmelerin Makro Ekonomi ve Finansman Risk Düzeyi İle İç Denetimin Risk Odaklı Yaklaşımla Kredili Satış Süreçlerine İlişkin Satış Prosedürlerini Belirleyerek Yürütülecek Süreçlere İlişkin Tavsiyelerde Bulunması Durumu Arasındaki İlişkinin İncelenmesi

Korelasyon tabloları incelendiğinde Türkiye'de enerji sektöründe faaliyet gösteren işletmelerin makro ekonomi ve finansman risk düzeyi ile iç denetimin risk odaklı yaklaşımla kredili satış faaliyetlerin yürütülmesiyle ilgili satış politikaları belirlemesi ve bu konuda tavsiyelerde bulunması durumu arasında Pearson Korelasyon Testinde 0,869 kuvvetinde önemli düzeyde pozitif bir ilişki olduğu, yine Spearman Korelasyon Testinde aynı düzeyde pozitif bir ilişki bulunduğu tespit edilmiştir. (Bkz. Tablo 3)

Coefficients $^{\text {a }}$

\begin{tabular}{|c|c|c|c|c|c|c|c|}
\hline \multirow{2}{*}{ Model } & \multirow{2}{*}{\multicolumn{2}{|c|}{$\begin{array}{c}\text { Unstandardized } \\
\text { Coefficients }\end{array}$}} & \multirow{3}{*}{$\begin{array}{c}\text { Standardized } \\
\text { Coefficients } \\
\text { Beta }\end{array}$} & \multirow{3}{*}{$\mathrm{t}$} & \multirow{3}{*}{ Sig. } & \multicolumn{2}{|c|}{ Collinearity Statistics } \\
\hline & & & & & & Tolome & VIГ \\
\hline 1 (Constant) & $\mathrm{B}$ & Std. Error & & & & Doterante & \\
\hline $\begin{array}{l}\text { Makro Ekonomi ve } \\
\text { Finansman Riskleri } \\
2\end{array}$ & $\begin{array}{l}, 476 \\
, 881\end{array}$ & $\begin{array}{l}, 276 \\
, 060\end{array}$ & ,869 & $\begin{array}{c}1,723 \\
14,691\end{array}$ & $\begin{array}{l}, 089 \\
, 000\end{array}$ & 1,000 & 1,000 \\
\hline
\end{tabular}

a. Bağımlı değişken: İç denetimin risk odaklı yaklaşımla kredili satış süreçlerine ilişkin satış prosedürlerini belirleyerek yürütülecek süreçlere ilişkin tavsiyelerde bulunması durumu

Regresyon Modeli: İç Denetimin Risk Odaklı Yaklaşımla Kredili Satış Süreçlerine İlişkin Satış Prosedürlerini Belirleyerek Yürütülecek Süreçlere İlişkin Tavsiyelerde Bulunması = 0,476+0,881(Makro ekonomi ve finansman riskleri) $+\varepsilon$ 


\begin{tabular}{|c|c|c|c|}
\hline & $\begin{array}{c}\text { İç denetim departmanının, ülkede } \\
\text { yaşanabilecek döviz kurlarındaki } \\
\text { dalgalanma durumuna karşı } \\
\text { alınması gerektiği düşündüğü } \\
\text { önlemler hakkında tavsiyelerde } \\
\text { bulunması durumu }\end{array}$ & $\begin{array}{l}\text { İç denetim departmanının, finansal } \\
\text { piyasalarda yaşanacak olumsuz } \\
\text { durumlardan kaynaklanan fiyat } \\
\text { düzeyleri ve faiz oranlarında } \\
\text { yaşanacak değişimlerin etkilerini } \\
\text { değerleyerek üst yönetime bilgi } \\
\text { sunması durumu }\end{array}$ & $\begin{array}{c}\text { İç denetimin kredili satış } \\
\text { faaliyetlerin yürütülmesi } \\
\text { ile ilgili satış politikaları } \\
\text { belirlemesi ve bu konuda } \\
\text { tavsiyelerde bulunması }\end{array}$ \\
\hline $\begin{array}{l}\text { Makro Ekonomi ve } \\
\text { Finansman Riskleri Pearson } \\
\text { Correlation } \\
\text { Chi-Square Tests Sig. } \\
\text { (2-tailed) } \\
\text { Spearman's rho Sig. } \\
\text { (2-tailed) } \\
\text { Correlation Coefficient }\end{array}$ & $\begin{array}{l}, 699(*) \\
, 000 \\
, 699(*) \\
, 000\end{array}$ & $\begin{array}{l}, 717(*) \\
, 000 \\
, 723(*) \\
, 000\end{array}$ & $\begin{array}{c}, 000 \\
, 869(*) \\
, 000\end{array}$ \\
\hline
\end{tabular}

* Korelasyon 0.01 seviyesinde (2-yönlü) belirgindir.

6.5. Türkiye'de Enerji Sektöründe Faaliyet Gösteren İşletmelerin Operasyonel Risk Düzeyleri İle İç Denetimin Risk Odaklı Yaklaşımla Operasyonlardaki Verimsizlik Sonucu Ortaya Çıkabilecek Sorun Veya Kesintilerin Hizmet Kalitesini, Maliyetler Üzerindeki Etkisini Değerlendirmesi Ve Üst Yönetime Raporlaması Durumu Arasındaki İlişkinin İncelenmesi

Türkiye'de enerji sektöründe faaliyet gösteren işletmelerin operasyonel risk düzeyleri ile iç denetimin risk odaklı yaklaşımla operasyonlardaki verimsizlik sonucu ortaya çıkabilecek sorun veya kesintilerin hizmet kalitesini, maliyetler üzerindeki etkisini değerlendirmesi ve üst yönetime raporlaması durumu ve işletmenin operasyonel risk düzeyi arasında Pearson Korelasyon Testinde 0,972 kuvvetinde önemli kuvvetli düzeyde pozitif bir ilişki olduğu, yine Spearman Korelasyon Testinde de aynı düzeyde pozitif bir ilişki bulunduğu tespit edilmiştir. (Bkz. Tablo 4)

Coefficients ${ }^{\text {a }}$

\begin{tabular}{|c|c|c|c|c|c|c|c|}
\hline \multirow{2}{*}{ Model } & \multirow{2}{*}{\multicolumn{2}{|c|}{$\begin{array}{c}\text { Unstandardized } \\
\text { Coefficients }\end{array}$}} & \multirow{3}{*}{$\begin{array}{c}\text { Standardized } \\
\text { Coefficients }\end{array}$} & \multirow{3}{*}{$\mathrm{t}$} & \multirow{3}{*}{ Sig. } & \multicolumn{2}{|c|}{ Collinearity Statistics } \\
\hline & & & & & & Toloment & VU厂 \\
\hline 1 (Constant) & $\mathrm{B}$ & Std. Error & & & & Tolerance & VIF \\
\hline $\begin{array}{l}\text { Makro Ekonomi ve } \\
\text { Finansman Riskleri } \\
2\end{array}$ & $\begin{array}{l}, 156 \\
, 969\end{array}$ & $\begin{array}{l}, 128 \\
, 028\end{array}$ & ,972 & $\begin{array}{c}1,222 \\
34,721\end{array}$ & $\begin{array}{l}, 226 \\
, 000\end{array}$ & 1,000 & 1,000 \\
\hline
\end{tabular}

a. Bağımlı değişken: İç denetimin risk odaklı yaklaşımla operasyonlardaki verimsizlik sonucu ortaya çıkabilecek sorun veya kesintilerin hizmet kalitesini, maliyetler üzerindeki etkisini değerlendirmesi ve üst yönetime raporlaması

Regresyon Modeli: İç Denetimin Risk Odaklı Yaklaşımla Operasyonlardaki Verimsizlik Sonucu Ortaya Çıkabilecek Sorun veya Kesintilerin Hizmet Kalitesini, Maliyetler Üzerindeki Etkisini Değerlendirmesi Ve Üst Yönetime Raporlaması $=0,156+0,969($ Operasyonel Riskler $)+\varepsilon$

6.6. Türkiye'de Enerji Sektöründe Faaliyet Gösteren İşletmelerin Operasyonel Risk Düzeyleri İle İç Denetimin Risk Odaklı Yaklaşımla Operasyonel Süreçlerde Hileli İşlemler/Suiistimaller Nedeniyle Yaşayabileceği Kayıpları Tespit Etmesi Veya Süreçlerdeki Suiistimale Açık Hususları Üst Yönetime Raporlaması Durumu Arasındaki İlişkinin Íncelenmesi

Türkiye'de enerji sektöründe faaliyet gösteren işletmelerin operasyonel risk düzeyi ile iç denetimin risk odaklı yaklaşımla operasyonel süreçlerde hileli işlemler/suiistimaller nedeniyle yaşayabileceği kayıpları tespit etmesi veya süreçlerdeki suiistimale açık hususları üst yönetime raporlaması durumu arasında Pearson Korelasyon Testinde 0,652 kuvvetinde önemli düzeyde pozitif bir ilişki olduğu, yine Spearman Korelasyon Testinde aynı düzeyde pozitif bir ilişki bulunduğu tespit edilmiştir. (Bkz. Tablo 4) 
Coefficients $^{\text {a }}$

\begin{tabular}{|c|c|c|c|c|c|c|c|}
\hline \multirow{2}{*}{ Model } & \multirow{2}{*}{\multicolumn{2}{|c|}{$\begin{array}{c}\text { Unstandardized } \\
\text { Coefficients }\end{array}$}} & \multirow{3}{*}{$\begin{array}{c}\text { Standardized } \\
\text { Coefficients } \\
\text { Beta }\end{array}$} & \multirow{3}{*}{$\mathrm{t}$} & \multirow{3}{*}{ Sig. } & \multicolumn{2}{|c|}{ Collinearity Statistics } \\
\hline & & & & & & & \\
\hline \multirow{2}{*}{$\begin{array}{l}1 \text { (Constant) } \\
\text { Makro Ekonomi ve } \\
\text { Finansman Riskleri } \\
2\end{array}$} & $\mathrm{~B}$ & Std. Error & & & & Tolerance & VIF \\
\hline & $\begin{array}{l}1,500 \\
, 625\end{array}$ & $\begin{array}{l}398 \\
, 087\end{array}$ & ,652 & $\begin{array}{l}3,771 \\
7,201\end{array}$ & $\begin{array}{l}, 000 \\
, 000\end{array}$ & 1,000 & 1,000 \\
\hline
\end{tabular}

a. Bağımlı değişken: İç denetimin risk odaklı yaklaşımla operasyonel süreçlerde hileli işlemler/suiistimaller nedeniyle yaşayabileceği kayıpları tespit etmesi veya süreçlerdeki suiistimale açık hususları üst yönetime raporlaması

Regresyon Modeli: İç denetimin risk odaklı yaklaşımla operasyonel süreçlerde hileli işlemler/ suiistimaller nedeni ile yaşayabileceği kayıpları tespit etmesi veya süreçlerdeki suiistimale açık hususları üst yönetime raporlaması $=$ $1,5+0,625$ (Operasyonel risk düzeyi) $+\varepsilon$

\begin{tabular}{|c|c|c|}
\hline & $\begin{array}{c}\text { Denetimin risk odaklı yaklaşımla } \\
\text { operasyonlardaki verimsizlik } \\
\text { sonucu ortaya çıabilecek sorun } \\
\text { veya kesintilerin hizmet kalitesini, } \\
\text { maliyetler üzerindeki etkisini } \\
\text { değerlendirmesi ve üst yönetime } \\
\text { raporlaması durumu }\end{array}$ & $\begin{array}{c}\text { İç denetimin risk odaklı yaklaşımla } \\
\text { operasyonel süreçlerde hileli işlemler / } \\
\text { suiistimaller nedeniyle yaşayabileceği } \\
\text { kayıpları tespit etmesi veya süreçlerdeki } \\
\text { suiistimale açık hususları üst yönetime } \\
\text { raporlaması }\end{array}$ \\
\hline $\begin{array}{l}\text { Operasyonel Riskler Pearson Correlation } \\
\text { Chi-Square Tests Sig. (2-tailed) } \\
\text { Spearman's rho Sig. (2-tailed) } \\
\text { Correlation Coefficient }\end{array}$ & $\begin{array}{c}972(*) \\
, 000 \\
, 972(*) \\
, 000\end{array}$ & $\begin{array}{c}, 652(*) \\
, 000 \\
, 652(*) \\
, 000\end{array}$ \\
\hline
\end{tabular}

\subsection{Risk Odaklı İç Denetimin Uygulanmasında Doğal ve Kontrol Risklerine Ait Önem Derecelerine İlişkin} Görüşlerin Değerlendirilmesi

İşletmenin, iş yapısından kaynaklanan riskler doğal risk faktörleri, iş süreçlerinde yer alan sistemsel ve beşerî iç kontroller ise kontrol risk faktörleri olarak adlandırılmaktadır. İşletme faaliyetlerinde söz konusu olan doğal risklerin alt risk bileşenleri olan operasyonel, çevresel, makro ekonomi, finansman riskleri, yönetsel riskler ve kontrol risklerinin alt risk bileşenleri olan iç kontrol, insan kaynaklı riskler (suiistimal, süreç uygulama riskleri vb.), bilgi teknolojileri riskleri, mali riskler ve karar alıcılar için enformasyon riskleri ile ilgili işletmelerince mevcut olan risklerin önem derecelerine ilişkin değerlendirmeleri önem derecesine göre 5'den 1'e sıralama yöntemi ile derecelendirilen anket ile analiz edilerek, katılımcıların düşüncelerinin ne olduğu hakkında fikir sahibi olmaya çalışılmıştır. Katılımcıların verdikleri yanıtlar dikkate alındığında, doğal risk grubunda yer alan işletmelerin makro ekonomi, finansman riskleri ve operasyonel riskleri; kontrol risk grubunda ise mali riskler, iç kontrol riskleri ve bilgi teknolojileri riskleri önemli risk bileşenleri olarak değerlendirilmiştir. Tablo 5' de katılımcıların risk odaklı iç denetimin uygulanmasında doğal ve kontrol risklerine ait belirttiği önem derecelerine ilişkin görüşlere ait tanımlayıcı istatistik sonuçlarına yer verilmiştir. 


\begin{tabular}{|c|c|c|c|c|c|}
\hline Tanımlayıcı İstatistik Sonuçları & $\mathbf{N}$ & Minimum & Maksimum & Ortalama & $\begin{array}{c}\text { Standart } \\
\text { Sapma }\end{array}$ \\
\hline $\begin{array}{l}\text { Doğal Riskler } \\
\text { Operasyonel Riskler }\end{array}$ & 72 & 3,00 & 5,00 & 4,2917 &, 51560 \\
\hline Çevresel Riskler & 72 & 2,00 & 5,00 & 3,5556 & ,60255 \\
\hline Makro Ekonomi ve Finansman Riskleri & 72 & 3,00 & 5,00 & 4,5694 & ,52612 \\
\hline Yönetsel Riskler & 72 & 3,00 & 5,00 & 3,8750 & ,57989 \\
\hline $\begin{array}{l}\text { Kontrol Riskleri } \\
\text { İç Kontrol Riski }\end{array}$ & 72 & 4,00 & 5,00 & 4,6389 & ,48369 \\
\hline $\begin{array}{l}\text { İnsan Kaynaklı Riskler (Suiistimal, süreç uygulama riskleri } \\
\text { vb.) }\end{array}$ & 72 & 3,00 & 5,00 & 3,6389 &, 51198 \\
\hline Bilgi Teknolojileri Riski & 72 & 3,00 & 5,00 & 4,1667 & ,62799 \\
\hline $\begin{array}{l}\text { Mali (Maddi Kayıp) Riskleri (Süreçlerde yaşanan suiistimal } \\
\text { vakaları sebebiyle yaşanabilecek maddi kayıplar, döviz, } \\
\text { faiz ve kredi işlemlerinden kaynaklanan belirsizliğin } \\
\text { azaltılamaması; işletme giderlerinin azaltılamaması) }\end{array}$ & 72 & 4,00 & 5,00 & 4,7639 & ,42767 \\
\hline $\begin{array}{l}\text { Karar Alıcılar İçin Enformasyon Riski (Muhasebe ve bütçe } \\
\text { sistemindeki verilerin doğruluğu, tamlık ve bütünlüğü, } \\
\text { mali ve operasyonel raporlamalar, maliyet muhasebesi, } \\
\text { sözleşmeler, vergi ve iş kanunlarının takibi ve uygulanmas, } \\
\text { kaynak tahsisleri ve performans değerlendirmeleri ile ilgili } \\
\text { riskler) }\end{array}$ & 72 & 3,00 & 5,00 & 3,9028 & ,50796 \\
\hline Valid N (listwise) & 72 & & & & \\
\hline
\end{tabular}

\section{Sonuç ve Öneriler}

Risk odaklı iç denetimin uygulanmasında finansal ve operasyonel risk faktörlerinin yönetimiyle ilgili işletmelerce gerçekleştirilen veya gerçekleştirilmesi planlanan çalışmaların önem derecesi ile ilgili görüşlere ilişkin değerlendirme sonuçları incelendiğinde katılımcıların, öncelikli olarak iç denetimin risk odaklı yaklaşımla operasyonel süreçlerde hileli işlemler, suiistimaller nedeniyle yaşayabileceği kayıpları tespit etmesi veya süreçlerdeki suiistimale açık hususları üst yönetime raporlamasının, finansal piyasalarda meydana gelen dalgalanmalardan kaynaklanan faiz oranı ve fiyatlardaki değişimlerin etkilerini değerlendirmesinin ve üst yönetime bilgi sunmasının işletmeleri için önemli olarak görüldüğü anlaşılmaktadır.

İşletmenin, iş yapısından kaynaklanan riskler doğal risk faktörleri, iş süreçlerinde yer alan sistemsel ve beşeri iç kontroller ise kontrol risk faktörleri olarak adlandırılmaktadır. İşletme faaliyetlerinde var olan doğal risklerin alt risk bileşenlerinden bazıları operasyonel, çevresel, makro ekonomi, finansman riskleri ve yönetsel risklerden; kontrol risklerinin alt risk bileşenlerinden bazıları ise iç kontrol, insan kaynaklı riskler (suiistimal, süreç uygulama riskleri vb.), bilgi teknolojileri riskleri, mali riskler ve karar alıcılar için enformasyon risklerinden meydana gelmektedir. Katılımcılar işletmelerince mevcut olan riskleri önem derecelerine göre değerlendirdiklerinde, doğal risk grubunda işletmelerin makro ekonomi, finansman ve operasyonel risklerinin; kontrol risk grubunda ise mali riskler, iç kontrol riskleri ve bilgi teknolojileri risklerinin önemli risk bileşenleri olduklarını ifade etmiştir.

Türkiye'de enerji sektöründe faaliyet gösteren firmaların risk odaklı iç denetim uygulama durumu işletme organizasyon yapısında risk yönetim bölümü bulunmasına ciddi oranda bağlıdır. Enerji sektöründe risk odaklı iç denetim uygulanma düzeyi işletmede risk yönetim biriminin mevcudiyetine göre farkl1lık göstermektedir. Çalışmada Türkiye'de işletmelerin kurumsallaşma süreçlerine katkı sağladığı düşünülen enerji sektöründeki firmaların halka açıklık ve yönetimde yabancı ortaklık durumunun mevcudiyeti ile işletmede risk odaklı iç denetimin uygulanma düzeyi arasında ilişki durumu incelenmiş, önemli düzeyde pozitif bir ilişki tespit edilmiştir.

İşletmelerin faaliyetlerini sağlıklı sürdürebilmeleri gelecek yatırım ve finansman planlarını rasyonel yapmaları, finansal yapılarını kontrollü olarak güçlü tutmaya çalışmalarına bağlıdır. İşletmenin doğru şekilde finanse edilip edilmediği, kredi 
verenlerin güvenlik payının yeterli olup olmadığını ve yabancı kaynaklar ile özkaynaklar arası ilişkiyi ortaya koyan finansal yapı oranları Türkiye'de enerji sektöründe faaliyet gösteren enerji firmaları için incelendiğinde önceki yıllara göre borçluluk oranının arttığı göze çarpmaktadır. Türkiye'de ana şebeke üzerinden gaz yakıtların dağıtımı sektöründe faaliyet gösteren 16 işletmenin ortalama kaldıraç (borçluluk) oranının 2014 yılında yüzde 65'den 2015 ve 2016 yıllarında yüzde 66'ya yükseldiği, elektrik enerjisinin üretimi, iletimi ve dağıtımı sektörlerinde faaliyet gösteren 302 işletmenin ortalama kaldıraç (borçluluk) oranının 2014 yılında yüzde 63 düzeyinden 2015 yılında yüzde 66’ya 2016 yılında ise yüzde 70'e yükseldiği görülmektedir. Bu durum enerji sektörünün özkaynağa kıyasla kredi verenler tarafından finanse edildiğini göstermektedir. Katılımcılar, makro ekonomi ve finansman risklerinin yönetiminde iç denetçilerin gerçekleştirecekleri risk odaklı denetim faaliyetleriyle (kur değişimlerinin etkilerinin analizi, faiz ve fiyat seviyelerindeki değişimlerin işletmeye olan etkisinin değerlendirilmesi gibi) işletme yönetimine yol göstermeleri gerektiğini düşünmektedir.

Türkiye'de enerji sektöründe faaliyet gösteren işletmelerin operasyonel risk düzeyleriyle iç denetimin risk odaklı yaklaşımla operasyonlardaki verimsizlik sonucu ortaya çıkabilecek sorun veya kesintilerin hizmet kalitesini, maliyetler üzerindeki etkisini değerlendirmesi ve üst yönetime raporlaması durumu arasındaki ilişki incelenmiş önemli düzeyde bir ilişsi tespit edilmiştir. Katılımcılar ayrıca, iç denetçilerin operasyonel süreçlerde gerçekleşecek hileli işlemler ve suiistimaller nedeniyle yaşanabilecek kayıplara ilişkin incelemeler yapılmasının operasyonel verimliliğin arttırılmasına katkı sağlayacağını düşünmektedir.

Hakem Değerlendirmesi: Dıș bağımsız.

Çıkar Çatışması: Yazar çıkar çatışması bildirmemiştir.

Finansal Destek: Yazar bu çalışma için finansal destek almadığını beyan etmiştir.

Peer-review: Externally peer-reviewed.

Conflict of Interest: The author has no conflict of interest to declare.

Grant Support: The author declared that this study has received no financial support.

\section{Kaynaklar}

Beasley, M.S. (2014). Developing effective internal controls using the COSO model. Raleigh, ABD: Enterprise Risk Management Initiative, $14-38$.

Gassmann, O. \& Kobe, C. (2006). Management von innovation und Risiko:Quantensprüngen der entwicklung erfolgreich managen. 2.Auflage, Springer Verlag, Berlin Heidelberg,

Sümer Göğüş, H. (2012). Risklerin saptanmast ve değerlendirilmesi, 1.Bask1. İstanbul: Türkmen Kitabevi.

Kara, S. \& Yereli, A. (2012). İç denetimde risk yönetimi ve İstanbul menkul kıymetler borsası - imalat sanayi sektöründe bir uygulama. Muhasebe ve Finansman Dergisi, 54(1), 65-86.

Kara, S. \& Yereli, A. (2013). Risk odaklı iç denetim uygulamalarında yabancı ortaklığın etkisi: İMKB uygulaması. Muhasebe ve Denetime Bakış Dergisi, 39(1), 41-64.

Pricewaterhouse Coopers. (2006). Her yönüyle kurumsal risk yönetimi, İstanbul: Pınarbaş Matbaacılık.

Türedi, H., Zor, Ü. \& Gürbüz, F. (2015). Risk odaklı iç denetim. Muhasebe ve Finansman Dergisi, 66, 1-20. 